\title{
Reproductive and behavioural risk factors of low birth weight among newborns in Al Thawra Hospital, Sana'a, Yemen
}

\author{
Idayu Idris, ${ }^{1}$ Manal Sheryan, ${ }^{1,2}$ Qistina Ghazali ${ }^{1}$ and Azmawati Nawi ${ }^{1}$
}

${ }^{1}$ Department of Community Health, Faculty of Medicine, UKM Medical Centre, Cheras, Kuala Lumpur, Malaysia (Correspondence to: A. Nawi: azmawati@ppukm.ukm.edu.my). ${ }^{2} \mathrm{Al}$ Thawra Hospital, Sana’a, Yemen.

\begin{abstract}
Background: Low birth weight can lead to infant death, especially during the first year of life.

Aims: To assess risk factors related to low birth weight babies in Sana'a, Yemen.

Methods: We conducted an unmatched case-control study of 252 women who came for delivery at Al Thawra Hospital, Sana'a, Yemen, between August and October 2016.

Results: Significant risk factors for low birth weight were: birth interval < 2 years; history of pre-eclampsia during current pregnancy; preterm gestational age < 37 weeks; and khat chewing or smoking during pregnancy. After controlling for all the confounders, only birth interval < 2 years was significantly associated with low birth weight.

Conclusion: Shorter birth interval is an important risk factor for low birth weight; therefore, improving maternal awareness of this should be emphasized during postnatal follow-up.

Keywords: low birth weight, prematurity, pre-eclampsia, khat chewing, smoking.

Citation: Idris I; Sheryan M; Ghazali Q; Nawi A. Reproductive and behavioural risk factors of low birth weight among newborns in Al Thawra Hospital, Sana'a, Yemen. East Mediterr Health J. 2020;26(11):1415-1419. https://doi.org/10.26719/emhj.20.061

Received: 14/05/19; accepted: 27/11/19

Copyright $@$ World Health Organization (WHO) 2020. Open Access. Some rights reserved. This work is available under the CC BY-NC-SA 3.0 IGO license (https://creativecommons.org/licenses/by-nc-sa/3.0/igo).
\end{abstract}

\section{Introduction}

Low birth weight (LBW) is defined as birth weight $<2.5 \mathrm{~kg}(1)$. Two main factors cause LBW: preterm delivery (<37 weeks' gestation) and growth restriction, or a combination of both (2). LBW is related to maternal biological, social and general health (3). Infants with LBW have almost 20 times greater risk of dying compared to normal-weight newborn infants (4). LBW is predictive of a newborn's health and survival, and can lead to death during the first year of life. Unfortunately, even if an LBW infant survives, they may face life-threatening conditions throughout their life and be exposed to chronic health issues in later life (4). According to the World Health Organization (WHO), there are an estimated 25 million LBW infants born each year worldwide, which comprise $17 \%$ of all live births, and about $95 \%$ of them are born in developing countries (5).

There is a high prevalence of LBW infants in Yemen, where $32 \%$ of all newborn infants have LBW (6). This study was conducted to assess the maternal sociodemographic, reproductive and lifestyle risk factors related to LBW in Sana’a City, Yemen.

\section{Methods}

\section{Study design and sampling}

This was an unmatched case-control study conducted at Al Thawra Modern General Hospital, located in Sana'a City, Yemen during August-October 2016. This hospital is one of the biggest referral hospitals in Yemen. The cases and controls were selected according to the inclusion cri- teria, that is, women who gave birth to a single live infant and who were resident in Sana'a City for at least 1 year. Women who had given birth to newborns weighing $<2.5$ $\mathrm{kg}$ were classified as cases, and women who had given birth to newborns weighing $\geq 2.5 \mathrm{~kg}$ were classified as controls. Exclusion criteria were newborns that weighed $<1.5 \mathrm{~kg}$ or $>4.0 \mathrm{~kg}$, twins, stillbirths, and infants with a visible congenital anomaly. From the medical records, cases were selected by convenience sampling while controls were selected by simple random sampling. All newborns were weighed within 1 hour after birth. Sample size was calculated using Open Epi version 3.01 using a formula one proportion. Based on a previous study in $\mathrm{Su}-$ dan, with a prevalence of LBW of $12.6 \%$ (7), the sample size calculated for this study was 252 mothers of newborns (126 cases and 126 controls).

\section{Data collection}

Data were collected from selected women through self-administered questionnaires and medical records. Questionnaires were administered via face-to-face interview and questions were closed-ended in nature (Yes/No answers). The questionnaires and medical records consisted of women's age, educational level, occupational status, birth parity, birth interval, history of previous abortion, history of pre-eclampsia during the current pregnancy, gestational age of the newborn, number of antenatal care visits, as well as khat chewing and smoking during the current pregnancy. Interviews were conducted by 2 welltrained female data collectors within the first 24 hours after delivery, and medical record data were extracted after the interview. The researchers trained the data collectors 
and supervised them during data collection and checked all the questionnaires to ensure accuracy.

\section{Ethical considerations}

The study was approved by the Medical Research and Ethics Committee of the University of Science and Technology, Sana'a, Yemen. Before starting the interview, the participants were informed about the purpose of the study and its benefits. Verbal and signed consent were obtained from the participants before data collection. The respondents were assured that all the information would be confidential and only used for this study.

\section{Statistical analysis}

All the data were analysed by SPSS version 24.0. Qualitative variables were described by calculation of frequency, and quantitative variables were represented by mean and standard deviation. Odds ratios (ORs) and 95\% confidence intervals (CIs) were calculated to measure the risk. $\chi^{2}$ and Fisher's exact tests were used to show significant associations between cases and controls, as well as association of various risk factors and LBW. We used multiple logistic regression to calculate the adjusted ORs (aORs) after controlling for all possible confounders, with the corresponding $95 \%$ CIs, for LBW concerning exposure of interest.

\section{Results}

A total of 126 cases and 126 controls were included in the study (Table 1). The mean age in the cases and controls was 25.9 (standard deviation; 7.06) and 25.2 (5.48) years, respectively. Most cases and controls were aged 20-29 years. In the case group, $67(53.2 \%)$ women did not complete their primary education and $59(46.8 \%)$ who did. In the control group, $58(46 \%)$ women did not complete their primary education and 68 (54\%) did. In terms of occupation, $116(92.1 \%)$ women in the case group were housewives and $10(7.9 \%)$ worked outside the home. In the control group, $113(89.7 \%)$ women were housewives and
$13(10.3 \%)$ worked outside the home. There was no significant association between cases and controls concerning sociodemographic and socioeconomic characteristics.

Birth interval $<24$ months, history of pre-eclampsia, preterm delivery, chewing khat, and smoking were significant risk factors for LBW (Tables 2 and 3). However, in multivariate analysis, the only significant risk factor for LBW was birth interval < 24 months $(\mathrm{aOR}=2.24,95 \%$ $\mathrm{CI}=1.017-4.952, P=0.045)$ after controlling for the effect of other predictors.

\section{Discussion}

LBW is a significant cause of morbidity and mortality among neonates and children (8). Infants' gestational age has a vital role in determining BW. There is an increased risk of LBW for premature infants ( $<37$ weeks' gestation). According to WHO, prematurity is the cause of LBW in about one third of LBW infants (8). The present study showed that LBW was significantly associated with preterm delivery, which was consistent with previous studies $(5,7,8)$. The reason for this might be that most of the fetal growth and weight gain is in the late period of pregnancy; thus, preterm infants receive fewer nutrients, which can lead to LBW. In this study, khat chewing during pregnancy was a significant risk factor for LBW, which was consistent with other studies $(9,10)$. This might be due to the influence of khat on reducing maternal food intake, which affects proper weight gain during pregnancy and fetal growth. Smoking during pregnancy was a significant risk factor for LBW, which is supported by most studies worldwide (11,12). The harmful components of cigarettes or hubble-bubble get into the maternal circulation and then to the placenta, affecting fetal growth and weight.

Recommendations can be made to reduce the prevalence of LBW. Screening should be conducted by healthcare professionals of pregnant women with high risks of delivering LBW infants, especially if the mothers have a birth interval $<24$ months. Furthermore, awareness

\begin{tabular}{|c|c|c|c|c|c|c|c|c|c|}
\hline \multirow[t]{2}{*}{ Sociodemographic characteristics } & \multicolumn{3}{|c|}{ Cases, $n=126$} & \multicolumn{3}{|c|}{ Controls, $n=126$} & \multirow[t]{2}{*}{$P^{*}$} & \multirow[t]{2}{*}{ OR } & \multirow[t]{2}{*}{$95 \% \mathrm{CI}$} \\
\hline & $\begin{array}{l}\text { Mean } \\
\text { (SD) }\end{array}$ & n & $\%$ & $\begin{array}{l}\text { Mean } \\
\text { (SD) }\end{array}$ & n & $\%$ & & & \\
\hline Age (years) & $25.92(7.06)$ & & & $25.26(5.48)$ & & & & & \\
\hline$<20$ & & 21 & 16.7 & & 17 & 13.5 & 0.301 & 1.45 & $0.71-2.96$ \\
\hline $20-29$ & & 70 & 55.6 & & 82 & 65.1 & & Ref & \\
\hline$\geq 30$ & & 35 & 27.8 & & 27 & 21.4 & & 1.52 & $0.84-2.75$ \\
\hline \multicolumn{10}{|l|}{ Educational level } \\
\hline Did not complete basic education & & 67 & 53.2 & & 58 & 46.0 & 0.257 & 1.33 & $0.81-2.18$ \\
\hline Completed basic education and more & & 59 & 46.8 & & 68 & 54.0 & & Ref & \\
\hline \multicolumn{10}{|l|}{ Occupational status } \\
\hline Housewife & & 116 & 92.1 & & 113 & 89.7 & 0.512 & 1.33 & $0.56-3.17$ \\
\hline Work outside & & 10 & 7.9 & & 13 & 10.3 & & Ref & \\
\hline
\end{tabular}

${ }^{*_{2}}$ Statistically significant at $\mathrm{P}<0.05$.

$C I=$ confidence interval $\mathrm{OR}=$ odds ratio; $\mathrm{SD}=$ standard deviation. 


\begin{tabular}{|c|c|c|c|c|c|c|c|}
\hline \multirow[t]{2}{*}{ Reproductive factors } & \multicolumn{2}{|c|}{ Cases, $n=126$} & \multicolumn{2}{|c|}{ Controls, $n=126$} & \multirow[t]{2}{*}{$P$} & \multirow[t]{2}{*}{ OR } & \multirow[t]{2}{*}{$95 \%$ CI } \\
\hline & n & $\%$ & $\mathbf{n}$ & $\%$ & & & \\
\hline \multicolumn{8}{|l|}{ Birth parity } \\
\hline 1 & 57 & 45.2 & 50 & 39.7 & 0.655 & 1.19 & $0.60-2.36$ \\
\hline 2 & 23 & 18.3 & 24 & 19.0 & & Ref & \\
\hline 3 or more & 46 & 36.5 & 52 & 41.3 & & 0.92 & $0.46-1.85$ \\
\hline \multicolumn{8}{|l|}{ Birth interval } \\
\hline$<24$ months & 33 & 47.8 & 20 & 26.7 & $0.009^{*}$ & 2.52 & $1.26-5.06$ \\
\hline$\geq 24$ months & 36 & 52.2 & 55 & 73.3 & & Ref & \\
\hline \multicolumn{8}{|l|}{ History of abortion } \\
\hline Yes & 27 & 21.4 & 23 & 18.3 & 0.527 & 1.22 & $0.66-2.27$ \\
\hline No & 99 & 78.6 & 103 & 81.7 & & Ref & \\
\hline \multicolumn{8}{|l|}{ History of pre-eclampsia } \\
\hline Yes & 27 & 21.4 & 10 & 7.9 & $0.002^{*}$ & 3.16 & $1.46-6.86$ \\
\hline No & 99 & 78.6 & 116 & 92.1 & & Ref & \\
\hline \multicolumn{8}{|l|}{ Gestational age } \\
\hline Preterm (< 37 weeks) & 38 & 30.2 & 1 & .8 & $<0.001^{*}$ & 53.98 & $7.27-400.53$ \\
\hline Full term & 88 & 69.8 & 125 & 99.2 & & Ref & \\
\hline \multicolumn{8}{|l|}{ No. of antenatal care visits } \\
\hline$<4$ & 44 & 34.9 & 35 & 27.8 & 0.222 & 1.40 & $0.82-2.38$ \\
\hline$\geq 4$ & 82 & 65.1 & 91 & 72.2 & & Ref & \\
\hline
\end{tabular}

* $\chi 2$ Statistically significant at $P<0.05$.

$C I=$ confidence interval $\mathrm{OR}=$ odds ratio.

\begin{tabular}{|c|c|c|c|c|c|c|c|}
\hline \multirow[t]{2}{*}{ Lifestyle risk factors } & \multicolumn{2}{|c|}{ Cases } & \multicolumn{2}{|c|}{ Controls } & \multirow[t]{2}{*}{$\mathbf{P}$} & \multirow[t]{2}{*}{ OR } & \multirow[t]{2}{*}{$95 \% \mathrm{CI}$} \\
\hline & n & $\%$ & $\mathbf{n}$ & $\%$ & & & \\
\hline \multicolumn{8}{|l|}{ Khat chewing } \\
\hline Yes & 83 & 65.9 & 66 & 52.4 & \multirow[t]{2}{*}{$0.029^{*}$} & 1.76 & \multirow[t]{2}{*}{$1.06-2.92$} \\
\hline No & 43 & 34.1 & 60 & 47.6 & & Ref & \\
\hline \multicolumn{8}{|l|}{ Smoking } \\
\hline Yes & 41 & 32.5 & 17 & 13.5 & \multirow[t]{2}{*}{$<0.001^{*}$} & 3.09 & \multirow[t]{2}{*}{$1.64-5.82$} \\
\hline No & 85 & 67.5 & 109 & 86.5 & & Ref & \\
\hline
\end{tabular}

${ }^{*} \chi 2$ Statistically significant at $\mathrm{P}<0.05$.

$\mathrm{CI}=$ confidence interval; $\mathrm{OR}=$ odds ratio.

raising and health education on how to carry on a healthy pregnancy should be focused individually. Improvement of lifestyle by all means, and avoiding smoking and chewing khat during pregnancy are essential. Pregnant women need access to suitable maternal health services, including antenatal care and nutritional counselling services.

\section{Conclusion}

Risk factors for LBW identified in this study can be reduced and prevented by improving maternal health education, especially on pregnancy spacing.

Funding: None

Competing interests: None declared. 


\section{Facteurs de risque reproductifs et comportementaux liés au faible poids de naissance chez les nouveau-nés de l'hôpital Al Thawra de Sanaa au Yémen}

\section{Résumé}

Contexte : Un faible poids de naissance peut entraîner la mort du nourrisson, en particulier pendant la première année de vie.

Objectifs : La présente étude visait à évaluer les facteurs de risque liés au faible poids de naissance des enfants nés à Sanaa au Yémen.

Méthodes : Nous avons mené une étude cas-témoins non appariés auprès de 252 femmes venues accoucher à l'hôpital Al Thawra de Sanaa, au Yémen, entre août et octobre 2016.

Résultats : Les facteurs de risque significatifs du faible poids de naissance étaient un intervalle entre deux naissances inférieur à deux ans, des antécédents de pré-éclampsie pendant la grossesse concernée, l'âge gestationnel prématuré inférieur à 37 semaines et la consommation de khat ou le tabagisme pendant la grossesse. Après contrôle de tous les facteurs de confusion, seul un intervalle entre deux naissances inférieur à deux ans était significativement associé à un faible poids de naissance.

Conclusion : La réduction de l'intervalle entre les naissances représente un facteur de risque important de faible poids de naissance; par conséquent, il convient de mettre l'accent sur une meilleure sensibilisation des mères sur ce point à l'occasion du suivi postnatal.

$$
\begin{aligned}
& \text { عو امل الخطر الإنجابية والسلو كية لانخفاض وزن المو اليد في مستشفى الثورة في صنعاء باليمن } \\
& \text { إيدايو إدريس، منال شريان، قستينا غزالي، أزماواتي ناوي } \\
& \text { الخالاصة } \\
& \text { الخلفية: يمكن أن يؤدي انخفاض الوزن عند الولادة إلى وفاة الرُضَّع، وخاصة خلال السنة الأولى من أعحارهم. } \\
& \text { الأهداف: هدفت هذه الدراسة إلى تقييم عو امل الخطر المتعلقة بالأطفال المصابين بانخفاض الوزن عند الو لادة في صنعاء باليمن. } \\
& \text { طرق البحث: أجرينا دراسة حالات وشو اهد فريدة من نوعها لما بجموعه } 252 \text { امر أة حضرن للو لادة في مستشفى الثورة في صنعاء باليمن، في الفترة } \\
& \text { بين أغسطس / آب و أكتوبر / تشرين البـ الأول } 2016 .
\end{aligned}
$$

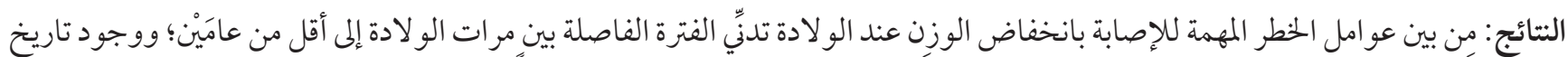

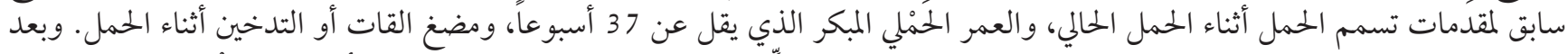

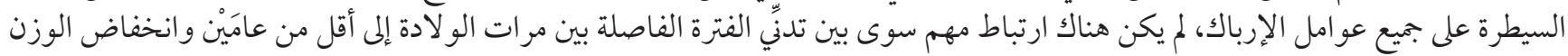

$$
\begin{aligned}
& \text { عند الو لادة. }
\end{aligned}
$$

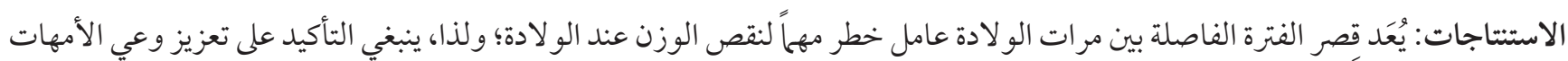

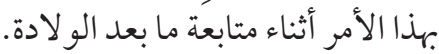

\section{References}

1. Low birthweight: country, regional and global estimates. UNICEF; 2004. (https://www.unicef.org/publications/index_24840. html, accessed 14 May 2020).

2. Bendhari ML, Haralkar SJ. Study of maternal risk factors for low birth weight neonates: a case-control study. Int J Med Sci Public Health. 2015; 4(7):987-90. http://dx.doi.org/10.5455/ijmsph.2015.20032015203

3. Deshpande Jayant D, Phalke DB, Bangal VB, D Peeyuusha BS. Maternal risk factors for low birth weight neonates: a hospital based case control study in rural area of Western Maharashtra, India. Natl J Commun Med. 2011 Oct-Dec; 2(3):394-8.

4. Child health USA 2011. Rockville, MD: US Department of Health and Human Services, Health Resources and Services Administration; 2011 (http://mchb.hrsa.gov/, accessed 14 May 2020).

5. Paramita S, Sharma N, Benjamin AI. Risk factors for low birth weight: a case control study in Ludhiana Punjab. Indian J Matern Child Health. 2009;11(1-4):9.

6. Riniker KS. Women's health in Yemen: factors influencing maternal and infant health, fertility rates, the public health care system, education, and globalization. J Global Health Perspect. 2012.

7. Bener A, Salameh KM, Yousafzai MT, Saleh NM. Pattern of maternal complications and low birth weight: associated risk factors among highly endogamous women. ISRN Obstet Gynecol. 2012; 2012:540495. http://dx.doi.org/10.5402/2012/540495 PMID:22991672 
8. Sutan R, Mohtar M, Mahat AN, Tamil AM. Determinant of low birth weight infants: a matched case control study. Open J Prev Med. 2014;4:91-9.

9. Demelash H, Motbainor A, Nigatu D, Gashaw K, Melese A. Risk factors for low birth weight in Bale zone hospitals, South-East Ethiopia: a case-control study. BMC pregnancy and childbirth. 2015 Oct 13;15:264. http://dx.doi.org/10.1186/s12884-015-0677-y PMID:26463177

10. Abdel-Aleem MA. Khat chewing during pregnancy: an insight on an ancient problem impact of chewing khat on maternal and fetal outcome among Yemeni pregnant women. J Gynaecol Neonat Biol. 2015; http://dx/doi.org/10.15436/2380-5595.15.004

11. Zheng W, Suzuki K, Tanaka T, Kohama M, Yamagata Z, Okinawa Child Health Study Group. Association between maternal smoking during pregnancy and low birthweight: effects by maternal age. PLoS One. 2016 Jan 21;11(1):e0146241. http://dx.doi. org/10.1371/journal.pone.0146241 PMID:26795494

12. Stojanović M, Bojanić V, Musović D, Milosević Z, Stojanović D, Visujić A et al. Maternal smoking during pregnancy and socioeconomic factors as predictors of low birth weight in term pregnancies in Niš. Vojnosanit Pregled. 2010 Feb;67(2):145-50 (in Serbian) http://dx.doi.org/10.2298/vsp1002145s PMID:20337097 